1998

\title{
Immanence and Identity: Understanding Poverty through Law and Society Research
}

Frank W. Munger

New York Law School, frank.munger@nyls.edu

Follow this and additional works at: http://digitalcommons.nyls.edu/fac_articles_chapters

Part of the Law and Economics Commons, and the Law and Society Commons

\section{Recommended Citation}

32 Law \& Soc'y Rev. 931 (1998)

This Article is brought to you for free and open access by the Faculty Scholarship at DigitalCommons@NYLS. It has been accepted for inclusion in Articles \& Chapters by an authorized administrator of DigitalCommons@NYLS. 
Review Essay

Immanence and Identity: Understanding Poverty through Law and Society Research

Frank Munger

Joel Handler \& Yeheskel Hasenfeld, We the Poor People: Work, Poverty, and Welfare. New Haven, CT: Yale University Press, 1997. Pp xii+282. $\$ 35.00$ cloth; $\$ 16.00$ paper.

Elizabeth Bussiere, (Dis)Entitling the Poor: The Warren Court, Welfare Rights, and the American Political Tradition. University Park: Penn State University Press, 1997. Pp.xi+210. $\$ 26.50$.

Herbert J. Gans, The War against the Poor: The Underclass and AntiPoverty Policy. New York: Basic Books, 1995. Pp. xii+195. $\$ 22.00$.

\section{Poverty as Politics}

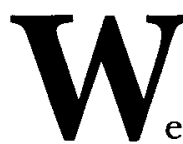

elfare policy has occupied a position in public political discourse since the 1960s as in few other periods of American history. The 1996 federal welfare reform legislation that swept away Aid to Families with Dependent Children in favor of statecontrolled programs supported by federal block-grant funding emerged from a momentous, long-running political debate occupying the foreground in every administration since the mid1960s.

Notwithstanding the important political role that welfare policy has played in the electoral politics of the past three decades, the most recent events might well pass into the annals of the Clinton presidency but for the troubling messages it has sent

I would like to thank Jim Atleson, Judy Munger, and Nancy Staudt for extremely helpful comments on earlier drafts of this review essay. I am grateful to Kathy Rose for assistance in preparing the references and to Joyce Farrell for providing assistance in preparing the manuscript. Address correspondence to Frank Munger, Faculty of Law, SUNY at Buffalo, Buffalo, NY 14260 (email: fmunger@acsu.buffalo.edu). 
about work and responsibility. The discussion of work, responsibility, the quality of family life, and its implications for the concept of citizenship has touched a sensitive part of the American psyche, and will not be soon forgotten nor will its implications soon be fully understood. Welfare reforms provide a part of the ideological underpinning for reducing citizenship to a single core-the right and duty to participate in the labor market.

While welfare reform has taken shape on the center stage of American politics, concerns about its effects on the poor have been swept aside by the insistence of political leaders that welfare has "failed." To say that welfare has "failed" suggests that we know and agree on what welfare should do and for whom, issues that raise fundamental moral and political questions about citizenship and equality. These issues have remained in the shadows, however, when welfare reform takes center stage. Failure to address them in the national discussion of welfare reform will have significance lasting far beyond the implementation of the harsh new reforms. What government provides, or fails to provide, for our poor is closely related to our understanding of governmental responsibility for the well-being of all citizens and thus has profound implications for the nature of community and the meaning of citizenship.

Welfare policies have been an important terrain of struggle in establishing the meaning of our commitment to one another. In We the Poor People: Work, Poverty, and Welfare, Joel Handler and Yeheskel Hasenfeld have identified the underlying values that render poverty programs particularly complex and unequal by design (pp. 9-10). The principal assumption shaping such programs is that self-support through work is a moral obligation. Poverty may result from an inability to work, and for those persons society should provide an adequate alternative to wages. For the remaining poor, poverty is presumptively a problem of attitude. Consequently, programs for the relief of poverty must first distinguish between the morally deserving and the morally undeserving poor. The deserving poor are identified by a limited number of characteristics that morally excuse them from work, principally disability, infancy, and more recently old age. Most others are judged morally lacking. Inability to find work at a living wage is not an excuse. Responsibilities of parenthood are not an excuse, especially for parents who do not conform to patriarchal gender norms and middle-income family structure. While poverty relief programs provide a kind of social right to equality, the "equality" welfare programs provide is based on the moral rehabilitation of the poor person rather than on changes in la- 
bor markets or redistribution of income that might bring material relief. ${ }^{1}$

The vision of moral citizenship projected by welfare law interweaves existing social practices of race, gender, and wealth inequality (Karst 1989, 1993). Thus, the failure of welfare administration to relieve poverty is not due simply to administrative ineffectiveness but also, as Handler and Hasenfeld point out, to the internal contradictions of a welfare policy formulated as symbolic politics and bearing little relationship to the lives and identities of actual welfare recipients.

In this essay, I review two recent contributions by law and society scholars to our understanding of the place of welfare law and policy in American society and a third book which suggests important issues that law and society scholars might explore. What is distinctive about much contemporary law and society research is its interest in the way that law and society are mutually constituted and organized. Poverty policies touch on fundamental perceptions of the relationship between individuals and community. The law and society field, through its growing understanding of the interplay between law and the practices of social and political life, may be well situated to help examine and appreciate the importance of the larger significance of welfare policies in American culture. Later in this essay I will suggest that welfare politics have played such a central role in shaping political consensus that we might refer to the practice of "governing through welfare." ${ }^{2}$ Through deeper understanding of the reasons for enduring resistance to more effective relief of poverty, we may also perceive realistic opportunities for change.

I also believe that the recent developments in welfare policy present the law and society field with an untapped opportunity to examine the interaction of politics, law, administration, and legal consciousness and to further its own project in developing a deeper understanding of law and social change.

\section{Getting beyond the Moral Politics of Poverty Research}

In important essays written in the 1960 s that have received too little attention in the intervening decades, Lee Rainwater (1970) and Herbert Gans (1969) examined the profound impact of the moral rhetoric about welfare on poverty research. Both observed that the moral underpinnings of poverty policy have

1 Ironically, the moral emphasis of our poverty programs has also shifted from helping needy children to rehabilitation of the parents, often ignoring the effects of moralsdriven restrictions that deprive dependent children of adequate food and shelter.

2 I owe this phrase to the work of Jonathan Simon, whose magnificent essay-in-progress "Governing through Crime" (1997) explores the emergence of a powerful contemporary commitment, woven into many domains of public and private authority, to maintaining a hierarchy among distinct cultural, racial, and class-based communities through risk management rather than through commitment to equal citizenship. 
presented a problem for poverty researchers. Rainwater (1970:9) suggested that moral issues were embedded in poverty research because the nonpoor who witness the plight of the poor often perceive poverty as a situation that they themselves could not endure. ${ }^{3}$ The perplexity and anxiety that such perceptions cause is typically resolved in one of two ways, Rainwater concluded, either by denying that the poor really live that way or by attributing characteristics to the poor that distinguish them from the rest of us. ${ }^{4}$ While most poverty researchers quickly become aware of the inadequacy of these two approaches to explaining poverty, they are often drawn to one of them and inveigh against the inadequacies of the other, limiting the reach of their research and its insight. Therefore, poverty research must first strive for a "phenomenologically valid account both of the inner reality of personal life and of the social exchanges that constitute the pattern of social life of the disinherited" (1970:26).

Herbert Gans (1969) took up Rainwater's argument in a contemporaneous essay, suggesting that researchers had responded to the moral debate by attempting to accumulate evidence supporting one moral extreme or the other. He issued a broad challenge to scholars to change the public discourse about poverty so that it promoted a deeper understanding of the poor as fellow citizens who are not morally different from the nonpoor. He concluded,

[I]nsofar as poverty research should focus on the poor at all, it should deal with behavior patterns, norms, and aspirations on an individual basis, relate them to their situational origin, and determine how much the behavioral norms related to poverty would persist under changing situations. Whether or not there is a persisting and holistic culture (or a set of subcultures) among the poor should be an empirical question. (P. 316)

He recommended that the research proceed by employing the methods of ethnography, in-depth interviews, life history, and participant observation, as well as large-sample social surveys. While these methods would illuminate the agency of the poor, the best method by far, in his view, would be a series of wellfunded social experiments that actually changed the circumstances of the poor in order to understand the capacity of the poor to adapt to change. ${ }^{5}$

3 Rainwater does not address the reasons why the poor themselves often accept the same moral stereotypes. This fact suggests that the moral response to poverty has less to do with the circumstances of the perceiver than with the framework for perceiving poverty provided by our culture, shared by poor and nonpoor alike.

4 Rainwater described a typology of simplified explanations of poverty that combine various elements of denial of poverty and treating the poor as not human. He concluded that these simplistic theories of the morals of the poor had shaped explanations of poverty not only in policy discussions but also in most poverty research.

5 The experiments should include better housing, well-paying and secure jobs, alternative combinations of work and income, superior schooling for children, and other measures. In the reedited version of the essay published in 1993, Gans notes that the 
In his most recent work on poverty policy, The War against the Poor: The Underclass and Anti-Poverty Policy, Gans documents the continuing problems created by the moral identity attributed to the poor. The persistence into the 1990s of the perception that the poor are morally undeserving is discouraging because Gans's challenge to scholars more than 30 years ago has born fruit in recent years in the form of a new and rich ethnography of poverty. Years after the call by Rainwater and Gans for a new look at the moral agency of the poor, studies of poverty are beginning to take the identity of the poor and the implications of interplay between individual action and social context more seriously. At long last a new frontier in poverty research has opened, and the misperceptions that underlie the national discourse on poverty are being addressed through nuanced ethnographic study (Handler \& White 1998; Gilliom 1997; Fine \& Weis 1998; Finnegan 1998; Edin \& Lein 1997; Zucchino 1997; Wilson 1996; Newman \& Lennon 1995; Rubin 1994; Duneier 1992; Anderson 1990; MacLeod 1987). The strength of the new look at poverty lies in its presentation of poor persons as complex moral actors and as more like the perceptions the nonpoor have of themselves. And, yet, in spite of such compelling narration of the lives of poor persons, public discourse about poverty has changed very little.

Although the new ethnographic writing about poverty has begun to challenge the moral stereotyping of the poor, public discourse about poverty continues to reflect the simplified moral assumptions Rainwater identified. Indeed, while calling for more nuanced research, Rainwater predicted that more sophisticated phenomenological and ethnographic approaches would not resolve the problem of simplistic moral interpretation.

In the end we are confronted with a paradox: The effort to develop an understanding of the condition of the disinherited that will neutralize the perplexity and anxiety the observer experiences will, even when it is effective in accomplishing this goal, result in radical ambiguity in the rational task of developing an existentially grounded diagnosis of the condition of that group.... Such accounts will inevitably present the social scientists and policymakers with . . . "hostile information," that is, information that challenges their most deeply held beliefs about what people are like, why they act as they do, and what this implies for political action. Yet if we are to provide a satisfactory intellectual grounding for systematic policymaking in this area, we must somehow achieve such a complex, accurate diagnosis rather than merely a satisfying and anxiety-reducing one (Rainwater 1970:26-27).

large number of evaluation studies since the publication of his original essay in 1968 have reinforced an important lesson about social experiments-that small inputs yield small effects. We have by no mean invested sufficiently in experiments creating resources or opportunities for the poor to say that we understand the aspirations of the poor and their capacity to change (p. 326). 
As Rainwater foretold, detailed accounts of the lives of poor have failed to raise the level of discussion, suggesting that it may never be enough to show that the identity of a poor person is complex (like the identities of the nonpoor), that poor persons display a range of moral conduct (like everyone else), and that welfare programs will not work when they are based on simplistic assumptions about the poor. Instead, research must create a more accurate moral identity for the poor, one that places poor persons in the same moral universe as the mainstream.

Understanding the persistence of the moral politics of welfare is a pressing issue for research. We might begin to understand the persistence of moral stereotypes as a reflection, in part, of the constitutive power of the policies and law through which the cultural foundations for welfare policies have been articulated. Poverty policies are grounded in strong cultural consciousness and institutional commitments. Poverty law carries powerful messages about the identities of the poor and the nonpoor, about responsibility for poverty, about whether the poor are to be treated with the same respect as the nonpoor, as dependent persons, or as objects of discipline. ${ }^{6}$ Therefore, scholars must not only describe the capacity of the poor to change-to perform as agents in their own improvement, as Gans argued-but must also examine how particular perspectives and policies become cognitively compelling, politically successful, and enduring. Poverty research must pay attention to the complex interaction between politics, law, and tolerance for poverty. Through such research we may begin to understand the public construction of the moral identity of the poor and the responses of the poor to their poverty. We may also learn valuable lessons about the administration of poverty policy and the responses of the public at large to the continuing presence of poverty and poor persons in our society.

\section{A Constitutive and Institutional Perspective on Law, Identity, and Poverty}

The role of law in maintaining, resisting, or changing the social order has been a central interest of scholars in the law and society field (Munger 1993, 1998). Early law and society studies suggested that the ability of law to bring about change or to influence everyday conduct might be quite limited; thus the promise of legal rights "on the books" was blunted by the complexities of achieving compliance with the law "in action." More recent law and society scholarship has pursued the development of increas-

6 Because of the close link between poverty laws and the social identity of the poor, we may think of poverty laws as a species of civil rights law. Poverty laws bear the same complex relationship to the experience and practice of interactions with poor persons that civil rights laws have to the experience and practice of citizenship of protected minorities. 
ingly nuanced understandings of the part law plays in the actions of officials and in the everyday lives of individuals. Many would now argue that the law plays a "mutually constitutive" role in the formation of meaning, understanding, expectations, and intentions in the flow of administrative and judicial action, and in daily life (Sarat \& Kearns 1993; Engel 1993; Yngvesson 1993; Engel \& Munger 1996; Munger \& Engel 1998). The presence of law shapes the identity of actors, the meaning of their actions, and the influence of the settings in which their actions occur. The potential "symbolic, discursive and constitutive effects" of law on organizations are being acknowledged and documented (Suchman \& Edelman 1996:929). At the same time, the interplay between law and social processes is mutual because the normative and cognitive influences in any social setting render the law "malleable, contested, and socially constructed" (ibid.). ${ }^{7}$

Scholars are revisiting the study of legal institutions, but with an understanding of the constitutive role of law as a source of cognitive and normative influence on meaning and action (see the comprehensive review by Suchman \& Edelman 1996). Processes of institutionalization structure the creation and administration of public policies like welfare. At the normative and cognitive level, over time problems and interests are defined for organization members through internal as well as external interactions. In time, the responses of courts, bureaucracies, and legislatures to material, personal, or political contingencies are shaped by the continuing influence of core traditions, ideologies, or doctrines through a process which Margaret Weir (1992:189) calls "bounded innovation." These core insights of the new institutionalism are particularly suggestive when applied to the problem of explaining the continuing influence of values and identities underlying welfare policies. At the same time, scholars concerned about poverty policy must explore means of changing this pattern, and they may find it useful to draw on the contemporary law and society project of studying the continuing patterns of inequality notwithstanding the complex, contingent, mutually constitutive role of law.

The three books reviewed in this essay illustrate the mutually constitutive evolution of welfare law and society through descriptions of the interplay between the symbolic and the cognitive force of law, the institutional processes of legislating, administering, and adjudicating, and the formation of our identities as individuals and citizens. ${ }^{8}$ These studies take the law's power to create

7 As Suchman and Edelman (1996:936) note, "even when actors lack the specific legal knowledge required for effective deterrence, they may nonetheless incorporate general legal categories into their general cognitive maps, allowing the law to frame and constrain perceptions of the world."

8 See studies by McCann 1994; Bumiller 1998; Yngvesson 1993. Indeed, the turn to "reflexive law" (Teubner 1983) suggests the importance of the distinction between particular settings in which law takes on specific meanings. I am interested in the way that 
identity for granted. As Handler and Hasenfeld explain at length in their work, poor law not only makes a fundamental distinction between deserving and undeserving poor, but in many respects creating this distinction is the poor law's primary purpose. Handler and Hasenfeld associate this profound moral distinction with a long history of attempts by governments to maintain the availability and discipline of the labor force, making dependency rather than need the key to poor relief. In turn, they note important links between the concept of dependency and gender, race, and class. The link between poverty policy and moral-political concepts of the deserving poor have maintained not only the labor market but also social distinctions that have been the historical basis for denial of full legal and political rights (Shklar 1991).

Bussiere's study in (Dis)Entitling the Poor: The Warren Court, Welfare Rights, and the American Political Tradition of the Supreme Court's handling of critical welfare rights cases shows that the identity created for the poor (and nonpoor) by welfare policies may be selectively promoted through political and legal institutions such as the Supreme Court. The poor are portrayed as undeserving of special constitutional protection because they have not been unfairly politically disadvantaged, but rather experience the condition of poverty because they have simply been less successful in making use of the social and economic opportunities afforded all members of society. Conversely, the nonpoor are portrayed as hard-working citizens who must not be arbitrarily made to support the poor by an undemocratic judiciary. Further, Bussiere demonstrates that these political and constitutional identities of the poor and the nonpoor have been selected from a reservoir of historically concrete sources in our culture that contains alternative identities for the poor.

Gans in The War against the Poor examines the persistence of stereotypes in public political discourse, policy, and administration. He identifies many functions of stereotypes that provide benefits to the nonpoor, including members of more affluent groups who use stereotypes of the poor to create value in their property or in their own behavior, administrators who defend their performance by blaming the poor for policy failures, and policymakers who employ convenient justifications for maintaining forms of inequality favoring dominant social and economic interests.

Research on the effects of poverty relief policies must take into account the power of the law to create identities for the poor. We need further genealogy of the identities selectively promoted by welfare policies. Where do they come from? How do they distort, and at the same time constitute, identity, and having

reflexivity legitimates autonomous interpretation of citizenship across many different settings; those who have written about reflexivity are often more concerned about the implications of the pattern for liberal legality and the future of autonomous general law. 
constituted identity, how does an identity affect the self-perceptions and actions of individuals? Law contributes to the creation and reproduction of identities, but we must explore precisely what role law plays since law alone does not constitute social life. As we move away from the simplified, generic identities created by welfare law, we embark on exploration of more complex processes that shape meaning and action and discover real lives that are more difficult to interpret than the stereotypes.

\section{Reforming Welfare by Reforming Work and Identity ${ }^{9}$}

For welfare policymakers the most difficult task is getting the problem right. The political discourse cannot be ignored, and there is too much history, too much research to be studied. Superficial interpretations of both abound and take all conceivable points of view. Administrators of existing programs have detailed information but little insight into what in their own behavior has contributed to the continuing failure of welfare. While program evaluation research and statistical studies of poverty have focused on the behavior of welfare recipients, evaluation research on individual welfare programs is not designed to examine what lies behind the continuing pattern of failures in program structure and administration. Without such knowledge, administrators can have no hope of developing poverty relief programs that might change the lot of the poor.

Joel Handler and Yeheskel Hasenfeld's We the Poor People: Work, Poverty and Welfare is a book for the ideal policymaker or administrator. The book provides a thorough critique of contemporary poverty policy together with proposals for comprehensive reforms. Of all the recent discussions and proposals concerning welfare reform, theirs may be not only the best informed but one of the wisest politically because its most important proposal is that we take moving welfare recipients into work seriously. Their analysis of welfare digs deep to explain why welfare programs have failed, drawing evidence from history, ethnographic and demographic studies, and evaluation research. By drawing on all of these literatures, Handler and Hasenfeld produce a coherent account of the continuing failure of contemporary welfare policy that links the cultural and political origins of policy with its effects on the poor. Recognizing that welfare reform has been driven by a moral discourse, not by the effectiveness of poverty relief, the authors situate their own proposals for welfare reform

9 The title Handler and Hasenfeld gave their manuscript-"Reform Work; Reform Welfare" - was rejected by Yale University Press over the authors' objections. The authors' original title was direct and programmatic, while the publisher's title strongly suggests a manifesto addressed to the converted, a goal far from the authors' intent. Yet, We the Poor People captures a subtle message missed by the original title of the book that the political feasibility of the authors' proposals for change will be closely connected with the identity of the poor. 
in the framework of moral concerns that underlies welfare policy. Within this framework, they are able to demonstrate that any welfare reform that fails to provide comprehensive support for low-wage workers is likely to reproduce the failures of past welfare-to-work programs.

We the Poor People has roots in law and society research. The authors bring theory-informed insight to the task of interpretation. The theory, developed more explicitly in the authors' earlier works (Handler 1978, 1996; Handler \& Hasenfeld 1991) and applied here, operates on two levels, first to focus attention on the importance of symbolic politics and second to ground welfare administration in institutional structure and practices.

One of their most important insights is that the identity of the poor explains both the symbolic politics and the continuing failure of welfare administration. Informed by theory, the authors are not only able to provide durable insights for policymakers but also a useful starting point for development of an enriched law and society research agenda. The relationship which Handler and Hasenfeld establish between the identity of the poor and poverty policy has many implications for law and society research on poverty.

\section{The Continuing Failure of Welfare}

The authors begin by noting that current welfare reforms are part of the historical pattern in which the same failed programs for poverty relief have been reenacted as "welfare reform." Welfare recipients have always been forced to work or to prove they are unable to work, and they have been broadly stigmatized as persons who do not wish to work. Further, Handler and Hasenfeld note that, in effect, welfare in the United States has always been a local program, enacted with high ideals at the federal level but administered at the county level under federal and state guidelines whose very complexity creates administrative discretion in determining compliance. Welfare programs intended to make welfare recipients work and placing responsibility on local officials have been enacted, in one form or another, again and again.

The authors first ask, Why have the same failed policies persisted for hundreds of years? They find the key to repeated enactment of ineffective policies in new institutionalist theory of symbolic compliance. ${ }^{10}$ Welfare is an exercise in "myth and

10 Organizations facing external pressure to meet contradictory goals or goals that are difficult to implement often engage in "ceremonial" compliance. The goals constitute a "myth" about the organization's purpose, and externally they serve the purpose of legitimating the organization's mission while internally they make administration of policies meaningful. The goals are a "myth" because in reality they may be only loosely coupled with actual performance through "ceremonial" compliance that gives the appearance of carrying out the symbolic mission (Meyer \& Rowan 1991). The practice of "myth" and 
ceremony" (Handler \& Hasenfeld 1991:11; Meyer \& Rowan 1991:41). The myth of welfare is that the poor are morally deficient and lack the will to work. The ceremony consists of putting a few model welfare recipients into jobs through welfare-to-work programs while failing to provide meaningful employment opportunities for most recipients (and for none of the nonwelfarereceiving poor). ${ }^{11}$

The myth of welfare not only contributes to a successful politics of welfare reform which preserves the symbolic capital that powerful social groups have invested in the work ethic, "family values," and other forms of moral dominance; the myth of welfare creates as well an identity for the poor that makes it easier to place the blame for failed welfare policies on the poor themselves. The stereotypical image of the "welfare recipient" has changed over time, but today the image is the young, African American, unmarried women, likely to be an addict, and who has children to get welfare. "Accordingly, welfare policy is deeply involved in preserving the moral order-the work ethic and family, gender, race, and ethnic relations. Welfare is fundamentally a set of symbols that conveys what behaviors are virtuous and what are deviant" (p. 4). The identity of the poor as morally deficient legitimates the policy of requiring work and placing the burden of finding work largely on the poor. This image, invalidated by an increasing body of research, is never questioned even when policies fail.

Most important, ceremonial compliance creates an impression that administrators are doing their job, and as a result programs seem to have been implemented as planned. If the programs are failing, the myth of welfare supports the explanation that welfare recipients themselves are "failing" to take advantage of the opportunities provided by public relief. Thus, the moral politics of welfare determines the nature of programs but also provides a ready excuse when the programs fail, justifying a new cycle of reform to tighten loopholes in the system for regulating the conduct of the poor.

"ceremony" can be an effective way of preserving the legitimacy and coherence of an organizational mission that cannot be implemented in fact.

11 Handler and Hasenfeld argue that the myth of welfare is tied to preservation of the moral order, most importantly the moral order underlying the labor market. From the earliest regulation of the poor, "the goal of relief . . . was not primarily to relieve misery but rather to preserve the work ethic" (p. 25). The myth of welfare is founded on a belief in the personal moral failings of the poor that make them dependent on public assistance, their failure to work, failure to marry, and failure to assume family responsibilities. The authors also see the symbolic politics of welfare connecting with other contemporary political currents, in particular the debate over the role of government and the suspicion that government has gotten too big, too expensive, and too indulgent of special interests who have put hard-working Americans at a competitive disadvantage. 


\section{Reading the New Research: Work Ethic and Welfare-to-Work Programs}

We the Poor People provides a detailed and informed summary of the new research on poverty and welfare-to-work programs. Because the identity of welfare recipients drives welfare programs, accurate portrayal of the poor who might take advantage of welfare is crucial to the assumptions on which programs are based. Reformers' misperceptions of the poor are revealed by the new research. Historically, welfare recipients have been more likely to be white than black, have had average-size families rather than large families, have been equally likely to be divorced or separated as to never have been married, and in their late 20s rather than teenagers. Never-married teen parents make up only a tiny fraction of welfare recipients (under 10\%), although they are demonized and made to represent the "problem" of welfare.

Much of the recent research has a direct bearing on the issue of work ethic. Welfare recipients make extraordinary efforts to leave welfare through work, the majority cycling off welfare into the job market after relatively short periods of time, only to be terminated involuntarily or to fail at work because of family demands (see Edin \& Lein 1997). Many others lack minimal skills or abilities to find work. While the job market has no sustainable work for these recipients, most keep trying , to find work. Thus, Handler and Hasenfeld show that recipients not only have a work ethic in principle but also validate their values by acting on them.

Moreover, poverty itself creates disadvantages for the poor, who may lack the necessary education, experience, and nurturing needed to become an employable adult. Poverty and lowwage jobs mean that the poor need both work and welfare. ${ }^{12}$ The authors conclude:

The effects of both poverty and low wage labor reinforce each other. Children growing up in poverty approach adulthood already overburdened. They face a labor market that offers little rewards. Most of these young adults will work, but a great many will remain in poverty. Many, especially women and their children, will have to rely on welfare. They, too, will struggle in the low-wage labor market, but most are also likely to remain in poverty. Neither welfare nor work will greatly improve their lives or the lives of the next generation. Self-sufficiency has been defined by policy makers as not being on welfare. It does not mean a decent life. (P. 56)

12 Work and welfare together may be insufficient to support and family, and, therefore, many women find a variety of other ways to support their families off the books (Edin \& Lein 1997). The efforts of poor women to maintain their families show that families require more resources than welfare or low-wage work provides, when work is available. Their efforts also show that they are often instrumental and rational in their strategies to achieve an adequate income in the face of inadequate welfare and inadequate income from low-wage work. 


\section{Reforming Low-Wage Work}

Behind the failure of welfare-to-work programs lie two major problems that Handler and Hasenfeld identify and thoroughly document. The first is the failure of welfare reformers to acknowledge the limitations of the private labor market to provide for the well-being of the poor who are motivated to work.

The history and structure of the U.S. welfare state illustrate how ... social welfare programs have reinforced dependence on the private labor market rather than providing alternatives to paid labor. ... But the labor market on which the American welfare state was constructed-full-time jobs paying a family wage to the male breadwinner-no longer exists for millions of families. We increasingly have a labor market of low-paying jobs, with the majority of women in the paid labor force and families requiring two and sometimes three wage earners. Thus the task is to reform not only the low-wage labor market but also related social welfare programs. (Pp. 20-21)

Mischaracterization of recipients and misperception of the availability of low-wage jobs translate into expectations for welfare-towork programs that influence their organization and administration and perpetuate their failure. ${ }^{13}$

The second cause of failure of welfare-to-work lies in the administration of existing programs through welfare offices that are dominated by a culture of compliance. In place of conventional program administration, the authors propose the creation of community-based, integrated employment services offices. Based on the failures of the past, they make a well-informed decision to reject mandatory participation in work programs. Voluntary participation lies at the heart of their proposed programs because only voluntary participation will encourage the formation of cooperative, rather than regulatory, relationships between staff and clients.

Their proposal to establish community-based employment services incorporates a further feature suggested by the failure of previous programs, namely, a three-tiered structure targeting dif-

13 The authors focus their attention on California's welfare to work experiments (the GAIN program), established in six counties in the 1980s. Each of the county experiments had a somewhat different emphasis. For example, Alameda County emphasized longer-term training and education leading to longer delay before entry into the job market but at a higher, sustainable wage. Riverside County emphasized short periods of training and quick entry into the job market, great emphasis on job development, and sanctions for participants who failed to comply. At the conclusion of the three-year experiment, two-thirds of the experimental participants in GAIN were not working and over half had never worked during that period. In Riverside, those who worked mostly remained on welfare because earnings were so low. There were small gains in earned income and small savings in welfare costs, and on the basis of these modest results the Riverside program has become the focus of much praise. There is little evidence of replicability and many reasons; say the authors, why it will be difficult to replicate elsewhere. Among other unique qualities, the Riverside program was directed by a charismatic leader and conducted in a strong job market, conditions that are difficult to universalize. 
ferent levels of service to subgroups with differing needs. The tiers would offer services for all persons seeking employment ranging from those who are ready for placement given appropriate day care, medical, and other supplemental services not provided by low-wage jobs, to those who will require substantial human capital investments before work will be a realistic possibility. The service centers would be open to all low-wage workers, and their services would be unrelated to receiving welfare. The authors thus conceive of a program in which clients with different needs receive different levels of service, including services for clients with long-term needs, and staff and clients "enter into mutually supportive, trusting, cooperative relationships" (p. 160).

The authors acknowledge that all of the institutional dynamics which have produced the "myth and ceremony" of current welfare policy and the culture of compliance in present welfare offices would have to be changed.

Effective implementation of social programs hinges, first, on the mobilization of external political and economic resources to support the program and, second, on the internal allocation of power and the selection of a service technology that is consonant with the desired outputs of the program. Tying the external and internal political economies into a coherent whole is a set of clear and explicit organizational objectives that emanate form an overarching organizational ideology (p. 160).

What they require in order to support their proposed service centers is "tight coupling" (Meyer \& Rowan 1991) of the agency's external, politically mandated mission and staff implementation that avoids merely symbolic commitment to change while permitting ceremonial implementation. ${ }^{14}$

\section{From the Politics of Poverty Policy to Law and Society Research}

Although aimed primarily at a policymaking audience, We the Poor People is informed by sophisticated theoretical insights from the law and society field. Its notable contribution as a theoretically informed synthesis of research may require emphasis. Because the book is also a work of advocacy, the authors do not pursue some of the implications of their analysis that may be of interest to scholars. Questions of great theoretical as well as practical importance lie just beyond the borders of the book; indeed, they seem more obvious and compelling as a result of the book's

14 They do not address the circumstances under which such a mission might be articulated within our present political culture and supported by budget-conscious politicians at federal, state, and community levels. Indeed, in some ways, loose coupling seems more suited to implementation of the radical reforms they propose in agency culture. In turn, the conditions for creating an agency culture of cooperation and support that motivates the staff and becomes the basis for self-evaluation as well as internal agency measures of performance seem difficult to specify absent a charismatic director such as the individual at the head of the Riverside agency. 
achievements in stating the long-standing issues that welfare reform has failed to address.

First, the book's proposals are transformative. Handler and Hasenfeld stay within the mainstream discourse of welfare policy by emphasizing work (not welfare), a commitment that is accepted by policymakers and their constituencies. Further, their goals emphasize creating opportunities to work, not income redistribution, and this, too, brings them within the traditions of the two-track American welfare state (see Marmor, Mashaw, \& Harvey 1990). ${ }^{15}$ Though their proposals are situated within this mainstream discourse, the proposals have radical implications. Handler and Hasenfeld propose fully funding the welfare-towork track, justifying their proposal in two ways. First, research findings fully support the existence of a work ethic on the part of most welfare recipients and challenge the distinction between deserving and undeserving poor. Inability to find sustained employment is usually not the result of lack of effort to find work but due to lack of employment opportunities at a living wage, lack of appropriate training, or both. Second, research also shows that other approaches, which may cost less, fail to produce long-term change in the employability of the poor. Thus, making the proposed programs work will require massive funding to support multiple lines of institutional change, from educational reform to health care provision to income security to work-supporting services such as child care.

Their proposals are radical for still more socially significant reasons. Not only will making work a viable alternative to welfare require massive funding, it will change the meaning of work. Work is central to the book's argument, making it hard to claim that its prescriptions violate core American ideals. By making work rather than welfare the problem, Handler and Hasenfeld subtly challenge fundamental principles of labor under capitalism. While they claim their proposals rely largely on the existing private labor market, in truth the effort to provide a stable income at a living wage would effect a substantial change in the labor market-by providing entitlements to adequate health and child care for all workers, expanded provisions for persons out of work, extensive services to help the unemployed become qualified for work, and an income floor. Their proposals not only require massive redistribution of income but also will restructure the labor market. Such a change would necessarily have other structural implications as well-for politics and for social hierarchy. Indeed, as Handler and Hasenfeld so ably demonstrate, welfare is symbolically linked to the maintenance of economic dominance, poverty, and hierarchical social categories. It is hard to

15 Marmor et al. confirm Handler and Hasenfeld's critique of welfare that the second track-the welfare-to-work/opportunity track-has always been less generously funded and has been loaded with conditions and hampered by short-term political goals. 
conceive of meaningful change without addressing, or neutralizing, these "functions" of welfare. ${ }^{16}$ By showing how fundamentally embedded welfare has become in our conception of American society, Handler and Hasenfeld have shown us just how difficult and complex the challenge of political change will be.

Second, the book's strong views on why policymakers have returned to the same old failed policies may provide useful starting points for further research. The authors' at times almost conspiratorial theory of the reasons for a demeaning and miserly approach to welfare invites careful examination of the processes that maintain the hegemony of a particular constellation of values in the formulation and administration of particular policies? ${ }^{17}$ Does the continuity of welfare policy come from a continuing hegemony by particular interest groups (see, e.g., Noble 1997)? Or is continuity embedded in the ideological or cognitive structure of institutionalized decisionmaking? If the latter, what role do capitalist institutions play?

The authors show that the identity of the poor is central to welfare policy. ${ }^{18}$ But precisely what role does the identity of the poor play? Will that identity have to be changed in order to alter the symbolic politics supporting inadequate welfare policies? There is, in fact, a great deal of popular support for alternative conceptions of poor persons and poverty relief, absent any mention of "welfare" (Kost \& Munger 1996; Williams 1995). The source of the "myth of welfare" is often politicians, who select and simplify messages to manipulate their constituencies. But what alternative political strategies might counter the traditional approach of politicians? Thus, the politics of identity is an important area for law and society research.

Third, the book's institutional analysis of weifäre administration should lead us to examine further whether the symbolic politics of identity is the only key to reform. If symbolic politics

16 Further, programs seem to have little potential to advance the fortunes of the least well off. Even though they may now be somewhat better off (but at continuing public expense), until we change many other institutions in society, the least well off remain at the bottom of a ladder with little chance of ascending because others in society still have greater advantages-unless we undertake serious redistribution.

17 The authors' own answer to' "Why have policymakers returned to the same old failed policies?" tends to rely on functional imagery, i.e., the function of welfare is to reinforce values underlying the capitalist labor market and other related institutions. Indeed, the authors at times seem to suggest conspiratorial motives: "As symbolic politics, as an exercise in myth making serving majoritarian values, welfare policy diverts attention from the fundamental issues of growing inequality, poverty, and the deterioration of the low-wage labor market. Instead welfare becomes the cause of societal ills" (p. 5).

of course, if welfare policies were a direct function of capitalism, there would be little variation in policies over time, little interest in the political struggles for and against reforms such as we have seen in the past decade, no viable alternative vision of welfare, and little point to Handler and Hasenfeld's efforts.

18 They have not been alone in making this claim. Herbert Gans, whose recent book is also reviewed below, argues that the identity of the poor is an important foundation for welfare policies and their administration. Indeed, he adds considerable sophistication and detail to Handler and Hasenfeld's otherwise broad-brush arguments. 
were as hegemonic as the authors suggest, their proposal to create integrated employment services centers to bring about the breakup of the culture of welfare offices would have little meaning. But their proposal does have meaning, and the conditions under which such centers might be contemplated pose a challenging research question. Loose coupling between mission and implementation not only makes the "myth" and "ceremony" of current welfare policies possible but may be equally important for reforming welfare. Symbolic politics are often decoupled from regulatory practice, and decoupling may create the open space in which such reforms can be successful. We should ask, therefore, What conditions would allow reforms of this kind to be proposed and to be implemented? A new era of administration is dawning in which traditional bureaucratic hierarchy is being loosened-states are ceding to counties and state agencies within counties the power to deal with block grants and the states are also creating contractual relationships in place of hierarchical administration. Such changes open up opportunities, and, as Handler and Hasenfeld's analysis suggests, these opportunities beg for new insights backed by empirical research to guide them.

Handler and Hasenfeld's success lies not in proposing a new rhetoric of citizenship and morality but rather in showing us how to use research to address questions about welfare that can be posed within the mainstream discourse. The brilliance of their proposals lies in their astute historical analysis laying bare the disjunction between the myth and ceremony of welfare administration and their exploitation of the internal contradictions of welfare institutions in order to arrive at a new perspective on welfare-to-work programs that is consistent with the mainstream's conception of moral citizenship.

\section{Poverty and the Political Ideology of Constitutional Rights}

Elizabeth Bussiere's (Dis)Entitling the Poor examines the Supreme Court cases decided between 1968 and 1970 that raised hopes of establishing a constitutional right to welfare and then dashed them. These cases have become icons in the history of the welfare rights movement, and more broadly they trace both the promise and the limits of the Warren Court's "new Equal Protection" doctrine. Bussiere incorporates into her analysis both a description of the New Deal origins of the Court's evolving equal protection doctrine and important details of the litigation as well as the social history of the cases. But she rejects both history and context as sufficient answers to her central question, namely, why the Supreme Court pulled back from what appeared to be a steady march toward a substantive right to welfare. 
Bussiere not only shows that contemporaneous political and legal developments seemed to make achievement of a constitutional right to welfare a real possibility, but she also argues that the right to subsistence was not alien to American traditions. As she describes, the right to subsistence was an element of populist political movements that had challenged business and government leaders from Revolutionary times to the present.

In the early 1970 s, when the critical welfare rights cases were decided by the Supreme Court, many historical factors seemed to favor the eventual development of a constitutional right to welfare. Since the New Deal, the Supreme Court had generally favored the idea that constitutional principles could change as society evolves. Thus, the Court had read the Constitution as offering protection for new rights that reflected the changing relationship between individuals and the community. Further, Legal Services Program attorneys were waging and winning a national campaign to advance the legal rights of the poor. The LSP movement, together with a legislative agenda advanced by the Nixon administration in 1970, which included a negative income tax or guaranteed minimum income, suggested that on two fronts a new right to provision of subsistence by the government was about to be recognized. Finally, the Court itself, employing its "new Equal Protection" analysis, had several times suggested that poor persons might constitute a "suspect class" triggering strict scrutiny of legislation that specially burdened the poor and all but guaranteeing a finding of unconstitutionality. The Court had declared a growing list of personal, political, and social freedoms to be fundamental constitutional rights and struck down legislation that interfered with them. Further, the liberal political leanings of a majority of the Court were well known.

Why, then, did the Court refuse to make minimal subsistence a fundamental right or poverty a suspect class? Bussiere argues that the explanation lies not only in the constellation of external forces pressuring the Court but also in the Court's institutional limits. In particular, she finds an implicit political theory, which she calls the "liberal persuasion," informing the opinions that prevailed on the Court. The importance of the ideological structure underlying the Court's decisions is apparent, she argues, because the mounting momentum of welfare rights litigation, the personal inclinations of the Justices, and the political context of the cases all pointed to the real possibility of a different outcome.

Bussiere's explanation draws its inspiration from new institutionalist writings-and their limitations. Pluralist theory-the mainstream of contemporary political science thinking about the courts-looks to conflict among competing interests that seek to influence the public decisionmaker. The behavioralist turn in pluralist theory makes it even less likely that normative considera. 
tions will play a role in explaining policymaking. ${ }^{19}$ In contrast, Bussiere argues that the effects of ideology, cognition, and normative factors cannot be ignored. Of particular relevance to Bussiere is examination of the social, historical, political, and ideological factors that shaped the interpretive framework of the Supreme Court's decisions. The new institutionalism is a useful source of insight because it "highlights moments in public policy making when the 'state' acts independently of societal pressures" (p. 15). More important, it suggests that political institutions have "a kind of life of their own ... influenc[ing] the self-conception of those who occupy roles ... . in ways that can give those persons distinctively "institutional perspectives"' (quoting Smith 1988:95). The roots of such patterns may lie, in turn, in "key mental or rhetorical structures' that might be independent influences in their own right" (again quoting Smith, p. 102).

Bussiere begins with an examination of the historical and political precedents in American society for treating the right to welfare as fundamental. At an early stage in the history of the American republic, workingmen's movements argued in favor of a more communal understanding of wealth production based in part on ideas drawn from America's Revolutionary period and the writings of Thomas Paine. Although proposals for applying such principles took many forms, at their core was an understanding that wealth could be produced only with the protection and assistance of the community. The resulting social compact between those who became wealthy and those who needed assistance embodied two important natural law principles: No one can alienate the right to self-preservation and reciprocal obligations bind communities together. In times of need, therefore, redistribution of wealth is in accordance with the social compact, and hoarding excessive wealth could even be considered a violation of the social compact. Similarly, the Progressive Era movement for mothers' pensions also has natural law roots-an idealization of the unique role of women as nurturers and as wives. This appeal resonated strongly with ingrained American conceptions of the family, and this in turn contributed greatly to the success of the movement.

Why, then, did the Supreme Court ignore these traditions when it came to extending equal protection doctrine to welfare rights? The answer lies in the political theory that filled the gaps in the Court's equal protection doctrine. Equal protection doctrine permitted application of very lenient standards for judicial

19 For a recent example see Noble (1997), who argues that welfare policies reflect 'interest group politics. Noble's book presents a discouraging picture of political gridlock but ignores both the tendency toward consensus between the major parties underlying recent reforms and the variety of perspectives that contend in the society. Institutional pressures to maintain a particular course notwithstanding, more diverse values are overlooked entirely. 
review to most state social and economic legislation but required strict scrutiny of legislation that placed unequal burdens on a "suspect class," such as racial or ethnic minorities, or on the exercise of fundamental rights. Legal doctrine was important because it established categories that the Court employed to strictly scrutinize governmental interference in some activities and with some groups while allowing state and federal legislators to exercise their own best judgment in regulating other activities and other groups. The doctrine in its most abstract form did not assign particular activities to one category or the other-social and economic legislation versus legislation affecting fundamental rights or unprotected minorities. Nor did it provide criteria for determining when unpermitted interference occurred, a distinction that turned in part on the difference between procedural rights and substantive rights. The Court's implicit political theory, its "liberal persuasion," helped fill these gaps. ${ }^{20}$ The particular political "persuasion" which prevailed is important precisely because it worked to foreclose some ways of framing and grounding the substantive welfare rights sought by advocates and to send the Court's arguments down other paths that the advocates might not have chosen.

The liberal persuasion reconstructed by Bussiere from the Supreme Court's post-New Deal opinions has three separate elements. The first element identified by Bussiere is proceduralism, which reflected the Court's determination to limit its use of the "strict scrutiny" standard of review to ensuring the right to meaningful access to political or judicial processes or to protecting groups historically barred from political participation. The second element of the liberal persuasion was the Court's broad standards for protection of free speech and other personal choices or activities. Some members of the Court employed natural law language to ground the rights being protected in a fundamental right to human dignity. Here, too, however, Bussiere finds the thrust of the opinions essentially proceduralist. The decisions barring interference with speech, and later privacy, were negative and content-neutral, declaring only that the government must grant maximum freedom to make private choices and may not impose its own moral choices on individuals. The third element of the liberal persuasion was the Court's hostility to local community standards for protection of rights and responsibilities and its favoring of a weak concept of national community. The Warren Court's strong support of the Bill of Rights freedoms throughout

20 She uses the term "persuasion" in place of ideology, doctrine, or theory to mean a "shared set of attitudes, beliefs, projected actions: A half-formulated moral perspective" (p. 121, quoting Marvin Meyers 1960). Her concept of persuasion does not refer to the aggregate personal attitudes of Justices but to a collective or shared framework that she gleans from the majority opinions of the Court. This framework draws on a stock of traditions, values, and ideas embedded in political culture. It determines the Justices' "comfort zone" in resolving difficult conflicts (p. 121). 
the 1950 s and 1960 s created national standards for the protection of constitutional liberties.

The elements of the liberal persuasion identified by Bussiere converged in a definitive refusal to find a constitutional right to welfare. Dandridge v. Williams (1970) provided the Court with an opportunity to resolve the tensions that existed between expressions of sympathy for the needs and human rights of the poor found in some of its opinions and the ideological framework that confined arguments supporting constitutional rights to particular channels. Dandridge concerned the constitutionality of the Maryland AFDC "family cap," a provision that set an upper limit on family welfare payments regardless of the number of children. Advocates argued that the denial of welfare to children whose presence would have entitled the family to additional support in the absence of the family cap implicated a fundamental constitutional right to subsistence and also discriminated against the very poor. In order to reach the conclusion that welfare rights advocates wanted, the Court would have either have to find welfare a fundamental right or find that wealth was a suspect classification. The court had given ample signals that it would not readily reach either conclusion. Yet, as Bussiere makes clear, the "persuasion" of the Court is no more than a "comfort zone" and not a rigid logic. The Court was troubled by poverty, and compelling facts might make a difference.

Unfortunately for the welfare rights movement, the Dandridge case was the "wrong" one to test the boundaries of the proceduralist categories that framed the Court's thinking. First, Maryland was not a Deep South state with a history of flagrant discrimination against blacks, an intangible that affected the Court's perception of the political significance of the disparate impact on the poor. Second, Maryland had relatively generous welfare benefits. Even those families denied a higher level of relief because of the family cap would not be left destitute. Thus, the categories determined by the doctrinal framework and given meaning by the Court's political persuasion made it difficult to separate the plaintiffs' constitutional arguments from the context of the case. ${ }^{21}$

21 Other factors also played into the Court's interpretation of the case within the framework of its liberal persuasion. The decentralization of the legal services program (LSP) meant that the leading advocates for welfare rights could not control the sequence in which cases were brought to the Supreme Court or the manner in which they were presented to the Court. Not only was the Maryland case the "wrong" one to present to the Court, but the attorneys presenting the case made critical mistakes in their advocacy. The LSP lawyers quoted from a pre-New Deal opinion relying on natural law as a basis for noninterference with the market economy. In the context of the Court's post-New Deal political persuasion, in each respect this opinion was a poor choice. Not only did the opinion rely on natural law, which the Court had emphatically rejected as an unacceptably subjective foundation for constitutional rights, the opinion also suggested that only economic rights were at stake and not fundamental individual rights. The Court's post-New Deal understanding of equal protection left social and economic policy in most cases to the legislature. As a final irony, the opinion supported laissez faire economic 
Bussiere's study parts company not only with the ideological determinists but also with those who might argue that the judges were completely free to follow personal values in rendering decisions about constitutional rights. Bussiere's examination deliberately focuses on historically contingent material and institutional circumstances as well as ideological factors. She shows that the context and the litigation strategy of the Dandridge case were both important factors triggering an outcome that was not inevitable. The ideological dimension of this study examines the complex interplay of doctrine, political traditions, personal values, and legal advocacy that produced landmark constitutional decisions. In turn, each element of this complex normative and cognitive framework has.its own history, contingent on the material forces acting within the society and its economy but also driven by historical choices in accommodating and rationalizing such pressures. The elements of political theory that infused the opinions of the Supreme Court between the New Deal and the late 1960 s originated in the interplay between material conditions of a capitalist economy and political adjustment by the Court in reconciling its role with liberal deference to progressive legislative instincts. Once established, this theory gave the Court ample reason to avoid interfering with legislative policies that only adjusted economic burdens of citizens, did not interfere with the exercise of personal liberties, and did not discriminate against an politically isolated and socially excluded group. Even with this framework in place, however, Bussiere is careful to note that the process of constitutional decision is open to the effects of contingencies created by advocacy and the inclinations of individual justices. Notwithstanding the element of contingency, however, Bussiere concludes, "the 'liberal persuasion' that flowed from and reinforced [the Supreme Court's] doctrine ultimately left little space for a constitutional obligation to fulfill the poor's most basic needs" (p. 151).

If Bussiere's study reveals the rich possibilities of the new institutionalism, it also leads to larger issues that her study alone cannot answer. Some questions arise because Bussiere cannot fully explore all the implications of her study. Others lie just beyond the borders of her study. For example, she does not explore the role of the recipients' identity and the constitutive power of law. Welfare rights advocates accepted the Court's own view that arguments for new constitutional rights were on far stronger grounds when the rights bearers were identified in universal (i.e., gender-neutral) terms. Presenting an argument for maternal rights would have required addressing the identity of female welfare recipients directly. We are left wondering about the effects

policies, a sentiment at odds with the interventionist, non-laissez faire argument for a right to economic subsistence. 
of the reluctance of male attorneys to take on the difficult issues associated with African American motherhood, single parenting, teenage pregnancy, and child rearing that would have arisen in arguments about maternalist rights. What were the consequences of presenting arguments that distanced these identity issues? For example, what was the identity of welfare recipients that was implicitly being presented to the Court? What identity were welfare recipients given in the Supreme Court's decisions? Surely some of the explanation for the Court's belief that the Maryland family cap indirectly benefited families with working parents lies in stereotypical views of the dependent welfare mothers and respectable working parents. It would have been remarkable if such stereotypes were not influenced by both gender and race. And what were the consequences of such implicit identities for further advocacy before the Court, litigation in lower courts, and in the treatment of welfare recipients by welfare administrators and the public at large?22

While Bussiere carefully notes her rejection of ideological determinism, she attributes powerful channeling effects to the doctrinal categories of equal protection. The conceptual barriers turn out to be critical factors in the Court's unwillingness to declare a constitutional right to welfare because "the judges ultimately proved unwilling to jump the doctrinal fence" (p. 116). However, Bussiere does not address a more fundamental issue, namely, the placement of the fences themselves. For example, at several points in her discussion she notes the broad differences among the Justices' interpretations of the meaning of positive versus negative liberty. Apparently the Justices themselves recognized that the difference between "negative" and "positive" liberties was dependent on perspective and would be open to debate. Yet, Bussiere herself does not discuss why particular Justices might have found a particular right, such as the right to subsistence, to be a "negative" or "positive" right. She assumes throughout her book that the right to welfare is a positive right and, thus, on the wrong side of the "doctrinal fence."

Equally important is her lack of attention to a related question of categorization, namely, how particular subjects of legislation came to be perceived by the Justices as matters of economic policy or as matters of affecting individual rights, a distinction critical to any analysis of rights with the framework of the Court's liberal persuasion. Here, too, there is evidence that the Court itself was uncomfortable with the choices that this dichotomy forced and could have been swung in a different direction. She notes that Justice Stewart's majority opinion in Dandridge expressed his ill-ease in attempting to place welfare laws and busi-

22 E.g., the Supreme Court's implicit identity discourse speaks to workers as well as the poor (see Kost \& Munger 1996; Matsuda 1997). 
ness regulation in the same category. Why, then, did Stewart ultimately accept a similar standard of review for both types of legislation?

Justice Brennan's role in engineering a favorable outcome after the Court's rehearing of the Shapiro (1969) case sheds light on the missing elements of her explanation. Brennan initially objected specifically to the class implications of the argument that a residency requirement discriminated against a constitutionally protected class, fearing that the economic institutions of the country might be brought into question. He was instrumental in forging a majority in favor of the plaintiffs after a rehearing in which all class elements had been eliminated from the plaintiffs' arguments. The Court's all but explicit acceptance of class inequality in American society as a necessary element of the capitalist economy and the social and political institutions that have grown up around it never makes its way into Bussiere's account of "liberal persuasion." And yet, capitalism turns out to be its centerpiece. Without the knowledge that the Court considered economic inequality to be socially and-politically fundamental and considered the state's own contribution to the ongoing production of economic inequality to be "neutral" rather discriminatory, we cannot fully understand the Court's categorization of welfare legislation as merely economic and the sought-for right to subsistence as an affirmative liberty rather than a right to be protected from governmental oppression and interference.

\section{Governing through Welfare ${ }^{23}$}

The principal challenge for progressive welfare reformers lies not in conceiving of effective ways to reduce poverty but rather in overcoming the barriers created by the moral politics of poverty. Handler and Hasenfeld's extraordinary effort to synthesize social science evaluation studies demonstrates that an effective policy can be created. But Handler and Hasenfeld propose no way to remove the symbolic political barriers to the reforms they set out other than by moral exhortation. The institutionalization of those barriers is explicated in part by the historical and institutional analysis of Bussiere, who finds continuing resistance to an affirmative right to subsistence in post-New Deal legal ideology

23 As acknowledged in note 2, this description parallels Jonathan Simon's "Governing through Crime," and my interpretation owes much to Simon's thoughtful reflection on patterns of governance and control. Indeed, regulation through welfare and regulation through crime control serve closely related purposes. Welfare-related ideology legitimates distributive patterns in society, while crime-related ideology legitimates the outer limits of the constitutional community. The two obviously overlap in their reinforcement of values underlying citizenship, legitimation of hierarchy and difference, and contribution to institutions that manage risk, control deviance, and sort persons into categories for appropriate social and physical separation or treatment throughout the social community. 
and in mainstream, liberal "political persuasion." Her analysis is particularly telling because it explains why the support for reform of many sympathetic liberals may be self-limiting in the context of constitutional interpretation. Yet, Bussiere's analysis leaves much still to be explained about the politics of poverty and the institutionalization of assumptions about poverty, the poor, and the private labor market that underlie the "liberal persuasion." Bussiere devotes little space to the analysis of non-elite versions of the "liberal persuasion" or to the core popular beliefs that strongly influence legislative reform, social movements, and litigation campaigns. Her descriptions of popular movements for subsistence payments to impoverished workers and to mothers show that popular consciousness can embrace a wide range of interpretations of the deservingness of the poor. The question remains why the politics of welfare has resulted in a policy of inadequate provision emphasizing punitive restrictions.

Herbert Gans examines the symbolic politics of poverty and its impact on American consciousness of poverty in his forceful response to welfare reform in the 1990s, The War against the Poor: The Underclass and Antipoverty Policy. I have already described Gans's call for redirection of poverty research three decades ago. Gans argued that poverty research reproduced the moral polarization of the politics of poverty without addressing whether the poor had the ability to respond to reasonable opportunities for change. In The War against the Poor, Gans targets a more critical issue: the continuing existence and importance of stereotypes of the poor. His frustration over the continuing stereotyping of the poor is understandable. Stereotypes, such as the label "underclass," provide the substance of much political rhetoric and the foundation for much misguided welfare policy. Knowing that policymakers and public alike lack actual knowledge of the way that the poor conduct their lives, Gans long ago proposed that scholars undertake research, ethnographic and interpretive in method and rich in detail, that would counter the stereotypes of the aspirations and motives of the poor. His hypothesis: There are no differences between the aspirations of the poor and the nonpoor, and there is no culture of poverty but rather vastly different opportunities and circumstances under which the poor and the nonpoor attempt to attain their aspirations. His hope: The stereotypes of the poor having been exploded, the poor will cease to be the object of oppressive welfare policies. Scholars answered this call, though Gans is critical of their response, but without apparent impact on the prevalence of stereotyping of the poor. Gans describes the historical progression of stereotypes, concluding his review with a sketch of the origins of the term "underclass." He describes the ways in which labels for the poor distort the identities and behavior of the poor and, most signif- 
cantly, he examines resistance to viewing the poor in other than stereotypical ways.

Here, as in his previous essays, Gans is at least as interested in provoking new research as he is in offering answers, and the strength of the book lies in the plausible hypotheses he suggests explaining the resilience of stereotypes. Resistance is not the result of mere ignorance, he argues; rather, perceptions of poverty continue because they bestow benefits and help deflect threats perceived by the nonpoor. Stereotypes of the poor maintain existing values, class hierarchies, and institutions of governance. Other scholars have argued, like Gans, that the history of our programs for social provision shows that welfare policies not only concern the poor but also have a broader significance for the nonpoor. In particular, welfare policies reinforce family and work values and maintain a competitive labor market. But Gans's veteran insight adds precision to the arguments and also probes a broader range of connections between the poor and the nonpoor. He suggests that stereotyping the poor helps the nonpoor manage threats and maintain social status and that it bestows benefits on government agencies, private businesses, social and economic classes, markets, and other institutions in society. Our beliefs about the poor have become a pervasive means of maintaining society as we know it.

Turning from causes to remedies, Gans blames the media, politicians, and scholars for perpetuating stereotypes. He strongly urges debunking the stereotypes. Journalists have a responsibility to become more informed and to convey a more balanced view of the motives of the poor. He also challenges scholars to pay more attention to the institutions that cause poverty. However, Gans's own analysis of the reasons why the stereotyping of the poor continues suggests that acts of conscience by a handful of committed professionals are unlikely to bring about change. His analysis suggests that stereotyping the poor plays such an important role in both government and governmentality that fundamental reform in our approach to welfare would require radically broadening our understanding of citizenship. Such a broadening of our concept of citizenship would require far greater acceptance of cultural differences and deeper commitment to the economic implications of equality.

\section{The Functions of Poverty}

The most important contribution of The War against the Poor is Gans's broad-ranging examination of potential explanations for the durability of stereotypes that characterize the poor and the continuing support for policies affirming such beliefs. He suggests that many separate mechanisms explain the willingness of the nonpoor to believe that the poor are undeserving, and he 
describes at length how welfare policies help displace social and economic threats to the nonpoor and how they bestow benefits on individuals and institutions.

Theories about how our treatment of the poor serves the interests of other groups in society and helps maintain major institutions are not new (Piven \& Cloward 1971; Skocpol 1992; Fraser \& Gordon 1992; Orloff 1993; Quadagno 1994). ${ }^{24}$ That literature is subject to several criticisms, however, each of which suggests directions for further research. Theories about why the poor continue to be considered morally undeserving have often assumed a functional relationship between welfare policy and the maintenance of social institutions like the capitalist economy or the patriarchal social structure. The implication of functional causality-the implication that there is process by which the unintended outcomes of welfare policies serve some larger goalshould be a prime focus of interest among law and society scholars. Careful historical studies, such as Bussiere's, suggest that welfare policies are not determined by the economic and ideological pressures of capitalism alone. They are also the product of contingent factors such as litigation, political opportunism, social movements, and the evolution of complex patterns of institutionalization. New institutionalist theory suggests that the initial assumptions underlying administration of major policies are often preserved notwithstanding pressures to change them because they continue to make administrative activity meaningful (Zucker 1991; Orloff 1993 makes a similar argument about post-New Deal welfare policy administration at the federal level). ${ }^{25}$

Second, even if welfare policies are governed by the benefits they bestow on the nonpoor, those benefits may extend well be-

24 Piven and Cloward (1971) argued that welfare maintains a reserve army of labor at a level of subsistence just below the lowest labor market wages and that this policy is relaxed only when the poor threaten social disorder. Others have argued that welfare policies have a constitutive power; that is, the policies influence the way members of society see and interpret the rest of society and their own position in it. For example, Handler and Hasenfeld suggest that welfare maintains political stability because it "diverts attention from the fundamental issues of growing inequality, poverty, and the deterioration of the low-wage labor market" (p. 5). Welfare policy redirects feelings of insecurity by focusing resentment on the "privileges" enjoyed by the poor who are subsidized at taxpayers' expense (p. 8). The same authors have also suggested that welfare policy "is fundamentally a set of symbols that try to differentiate between the deserving and the undeserving poor in order to uphold dominant values such as the work ethic and family, gender, race, and ethnic relations. In this sense welfare policy is targeted not only at the poor but equally at the nonpoor, through the symbols it conveys about what behaviors are deemed virtuous or deviant" (Handler \& Hasenfeld 1991:11). Even Marmor et al.'s (1990) mainstream interpretation of welfare makes patently clear that welfare has never been about the relief of poverty.

25 Much recent law and society research supports the more indeterminate view of the relationship between legal domination and political interests (Calavita 1992; Shamir 1993; Simon 1997; McCann 1994; Ewick \& Silbey 1992). Like the welfare rights litigation of the 1970 s, contemporary welfare reforms provide examples of both the opportunism guiding welfare policies and the tendency for dominant social groups to control the agenda of reform (for a more fully documented argument see Kost \&c Munger 1996). 
yond supporting deep structures such as the market or the patriarchal family. On closer examination, the causal connections between adoption or administration of welfare policies on one hand and major institutional and ideological features of our society on the other is complex, indirect, and contingent on motives created by more direct benefits to institutional actors. But research must attempt to move beyond the conclusion that the significance of policy is complex and contingent. To understand the functions of welfare, therefore, we have to examine specific and direct effects of welfare policies on politicians, legislators, administrators, the public, or recipients themselves that might, over time, contribute to the effects of welfare on a larger scale.

In contrast to the broad functional theories of the maintenance of poverty policies, Gans describes two specific mechanisms supporting the stereotypes that guide welfare policies. First, the poor are perceived as a threat to the nonpoor. Perceived threats reinforce stereotypes (rather than the reverse) when they serve the purpose of displacing blame for general problems in society onto the poor. Gans suggests that we need "systematic research on why the better-off stereotype the poor as undeserving and why they perceive imaginary threats from them as actual. ... The results will probably show that many such threats are displaced" (p. 77). Second, he plausibly links stereotyping to immediate, specific, and concrete benefits for individuals and organizations. Welfare policies thus reinforce the identity of the poor as undeserving because that identity provides immediate benefits whatever its significance for the maintenance of other societal institutions. ${ }^{26}$

Further, the nonpoor perceive threats to both their security and their values from the behavior of the poor. ${ }^{27}$ Even though, as Gans notes, "trends in the frequency of street crime seem to bear little relation to the fear of crime" (p. 78), fear of crime pervades perceptions of physical space, race, and class characteristics of the poor, responses to inner-city culture, and public policies that connect or separate social groups. Further, there is widespread belief that the poor pose economic threats, including threats to property values (physical proximity to the poor and racial subgroups of the poor), to the public fisc (welfare expenses), and to American job holders (immigrant labor). Finally, the nonpoor

26 While proximate benefits provide the motivation for stereotyping, those benefits often acquire their value as a result of a larger ideological, political, or economic organization of society. In this way stereotyping reinforces the larger pattern while providing immediate rewards to an actor with only a limited stake or no perceived in the larger pattern.

27 Gans, like Handler and Hasenfeld, sees a connection between such perceived threats and recent welfare reforms: "Reaction is exaggerated in an economy in which they [people] worry about their own position and where many are asked to work harder than in the past which also helps explain the desire to put recipients to work even when there are no jobs for them" (p. 82). 
perceive threats to their moral values from the behavior of the poor. ${ }^{28}$

All such threats reinforce stereotypes of the poor when they displace blame for problems with which the poor have little or nothing to do, for example, the worsening conditions of cities, the decline in family values, or the changing norms among young people. Two problems make the hypothesis of displaced threats challenging. First, while the nature of poverty and the characteristics of the poor have changed, the fears of the undeserving poor and the hostility toward them have not changed as much. We must understand why the stereotype has remained more constant than the nature of the apparent threat. Second, displaced threats are difficult to detect through standard social science research.

Gans does not draw attention to the important role that interpretive research methods might play in exploring the existence and nature of such threats. However, contemporary scholars, including law and society scholars, have been successful in unpacking multiple layers of meaning about identity and causation to understand the normative responses of the poor (White 1993; Ewick \& Silbey 1992; Sarat 1990) and the nonpoor (Ewick \& Silbey 1998; Yngvesson 1993; Newman 1988; Greenhouse 1986; Shapiro 1986).

A second mechanism reinforces stereotyping of the poor. Gans's exploration of the possible beneficial effects of the existence of the poor for the nonpoor provides an important framework for further research. While threats attributed to the poor may support stereotyping, stereotyping the poor also has beneficial consequences for the nonpoor. Even though benefits accrue to the nonpoor, Gans observes that at first they are often unintended benefits. However, he notes, "[w] hatever their origin . . . once these functions exist and produce benefits, their beneficiaries may develop an interest in them and even establish interest groups to defend them" (p. 91).

The potential benefits derived from stereotyping the poor are of three types: reinforcement of the values and identity of the nonpoor, using the poor as scapegoats for institutional failures, and supporting the private labor market. Stereotyping the poor creates value for and reinforces the identity of the nonpoor by

28 American popular ideology holds that bad behavior is caused by bad values, not by an inability to act in accord with good values. Therefore, many members of the public infer that the deviant behavior of the poor is caused by values that differ from those of the mainstream. Even the poor themselves perceive the behavior of the poor in this way, characterizing welfare recipients and even themselves as "lazy," even though on closer examination we may conclude that they have mainstream values and attempt to live by them. Even the self-perceptions of the poor have been colonized by popular views of their morality (see White 1993; Williams 1995). Gans observes that while it is questionable whether the nonpoor behave in accord with the values they hold as standards for the poor, the nonpoor are better able to conceal and avoid the effects of deviance. 
justifying avoidance of the "dangers" posed by the poor, by making the nonpoor feel superior as possessors of traits that are distinct from the traits of the poor, by reinforcing the nonpoor's deservingness, by reinforcing the moral values of the nonpoor, by creating a class of popular-culture villains from which moral lessons (and commercial sales) can be derived, by contributing to spatial stigmatization that justifies patterns of exclusion and social control. Each of these benefits is tied to concrete practices and modes of behaving on the part of nonpoor individuals or institutions-public behavior, policing, land use regulation, decisions about placement of public transportation routes, and other decisions dependent on evaluation of public interests or needsthat might be hard to justify without the stereotype of the poor.

Additionally, says Gans, benefits accrue from scapegoating the poor by blaming them for systemic and institutional failures, such as the failures of human services agencies who evade their responsibilities for administration of effective poverty relief policies by characterizing the poor as unresponsive and irresponsible. Shifting blame from public institutions to the poor has become a major industry during recent waves of welfare reform as liberals and conservatives alike proclaim that it is the poor's own culture of poverty that is responsible for their impoverishment and until the poor change they will remain poor.

Finally, stereotypes have well-known economic functions, such as providing the raison d'être for the human services industry that separates and treats the undeserving poor; or keeping the poor out of the mainstream labor force and forcing them to the margins of the labor market where they serve useful roles; providing a reserve army of desperate workers for the formal, informal, and underground economies; and becoming providers of illegal goods desired by many nonpoor.

\section{Welfare Governmentality}

Gans's description of the many processes that support stereotyping is particularly useful because it identifies motivations and intentions that we can examine closely through empirical research. The number and range of micro-mechanisms maintaining the identity and powerlessness of the poor establishes a pervasive and important social distinction between deserving and undeserving. Welfare is deeply implicated in governmentality, the replication of power in "tiny theaters" of control throughout society (Foucault 1977; Hunt 1994).

Gans's description of the functions of poverty shows how welfare is implicated in governmentality. Stereotyping persists because many of the benefits bestowed by stereotyping the poor are perceived and understood as beneficial by politicians, welfare administrators, and the public at large. Therefore, stereotyping the 
poor is employed as a strategy in governance, and it is not merely an unintended consequence or cultural pattern that arises from mediated or indirect causes. Politicians are well aware of the benefits of a simplifying stereotype, though they may not be fully aware of the particular distortions they are reinforcing through their symbolic politics. Suburban residents manipulate the concept of "blight" and the stereotypical identities of those who cause blight in symbolic politics affecting neighborhoods. Likewise, inner-city schools, mostly because of who attends them, become the unspoken "other" that proves the superiority of suburban schools and justifies elitism within those schools. Public administrators rely on sharing a sense of the meaning and purpose of an agency with other staff members. Their shared sense of meaning is created in part by the professional discourses they employ to describe what they do and in part by the "myths" they use to legitimate the agency externally. Discourses that suggest that what they do is effective notwithstanding the failure of their clients have an obvious appeal. Professional and political discourses that incorporate stereotypical characterizations of the poor have just such reinforcing implications concerning administrative effectiveness, and they may readily become part of the basis for the shared meaning of the activities of an agency, whether a welfare office, a department of labor, a housing inspection office, or a motor vehicle licensing office.

Still other effects of stereotyping identified by Gans illustrate governmentality, even though he does not describe them in this way. For example, Gans suggests that welfare reforms requiring the poor to submit themselves to harsh work requirements serve the purpose of psychologically "displacing" the economic insecurity of a large group of American workers. Notwithstanding any psychological displacement of insecurity, some benefits derived from effects of these reforms were intended. First, the desire of a large part of the American public to equalize the burdens of widespread economic insecurity secured political support for strict work requirements for welfare recipients. Thus, work requirements may well have displaced the anxiety of workers, but they also served an explicit purpose embraced by a large part of the public. Second, support for strict limits on welfare resulted not only from the desire of the American public to equalize economic insecurity but also from a successful effort by pro-market conservatives and business to promote the belief among wage earners that economic insecurity is necessary, normal, and legitimate (Kost \& Munger 1996; Matsuda 1997). ${ }^{29}$ Both interests were

29 Here we need not adopt a conspiracy theory. Belief in the inevitability of insecurity and responsibility of workers for their own economic well-being is a widely accepted discourse (others also exist) that leads workers to accept declining wages and criticize their unions and leads welfare recipients to criticize the laziness and dependency of other welfare recipients and even themselves. 
served by placing restrictions on welfare and punishing welfare recipients for not working. Belief in the undeservingness of the poor made it possible to take for granted that the poor should be made less secure, and thus made morally more deserving. The stereotype also helped weaken support for a plausible alternative policy, namely, making all workers more secure, because the stereotype is based on the assumption that no one is entitled to be more secure. ${ }^{30}$ Thus, stereotyping the poor may have aided "displacement" of anxiety through enactment of new limits on welfare, but stereotyping was also a factor in welfare reform as a intentional strategy for the exercise of political power.

Jonathan Simon (1997) has brought to our attention the increasing importance of the image of the other in American governance. Simon has demonstrated that the growing divisions among racial groups and between rich and poor have greatly altered our expectations for and practices of governance. The fact that such divisions are marked by differences in culture and political perspective makes consensus, negotiation, and reconciliation of conflicts among the interests of these groups increasingly difficult. ${ }^{31}$ Simon argues that an image of the criminal "other"-a person of color, poor, predatory, and urban-drives a wide range of public policies. The identity of the other legitimates policies of containment, separation, statistically based crime prevention, and punishment that affect not only criminal justice but also. land use, transportation, public funding of schools, national electoral politics, and other major institutional arenas in which governance structures social interaction.

Welfare, like crime, is also a means of governance. Welfare recipients, like criminals, are stereotyped, reinforcing an image of an "other" whose morally undeserving behavior explains and motivates policies of redistribution and regulation. Welfare dependency, like crime, is perceived to be a pervasive threat. Dependency has become the paradigm for worker resistance to reduction in employment security, benefits, and representation (see McCluskey 1997). Workers' benefits not related to the bot-

30 Historians have discovered that stereotyping has been a frequent factor in the origins of specific welfare policies, as motivation, for example, for Roosevelt's rejection of universal old age provision in order to differentiate social security from the dole, a program for the undeserving poor (Katz 1986). Similarly, Southern senators manipulated racist images of welfare recipients to defeat Nixon's proposed guaranteed income program (Quadagno 1994).

31. This change is reflected in the evolution of regulation in the "tiny theaters" of social control that make up governmentality. Culture-free regulation through spatial separation is replacing interactive communication and collective choice. Containment of norm violators is replacing disciplinarity and rehabilitation. Risk management is replacing democratic choice and interpersonal managerial decisionmaking. When the social connections have broken down between individuals involved in the exercise of power (which Foucault (1977) identifies as the foundation for disciplinarity and the exercise of decentralized power), power is then exercised by means that rely on no mutual interaction at all but rather on management by an algorithm designed into the system (Simon 1997). 
tom line are a form of economic fat, privilege, and immoral dependency, the mirror image of efficient, market-driven and, therefore, fair labor policy. Like crime, welfare and the stereotypes that it sustains help broadly constitute the relationship between social hierarchy and social order.

\section{Governmentality and Identity}

The rollback of welfare, like the new politics of crime control, proceeds from strong assumptions about the behavior of the poor and what they imply about how the poor should be handled. Contemporary welfare reform is just one of many related changes in governance supported by stereotyping dependent and outsider groups. Gans does not underestimate the difficulty of changing our approaches to poverty and, more generally, our approaches to economic and social inclusion of the poor. He addresses this problem, in part, by urging a campaign to debunk stereotypes, but his own description of the entrenchment of stereotypes makes it clear that this will not be sufficient to create political change. Changing governmentality founded on the identity of the poor will not be a simple matter of disseminating different information.

When law fails in its promise to become an effective enabling force for protecting equal rights of citizenship in the welfare state, we are left with "the long walk home ... to politics" (Simon 1992). But what do we know that might guide politics? The question is how to think about welfare politics. This final task for law and society scholars, following Gans's lead, begins by examining the mutually constitutive role of images of the poor, welfare policies, and the practices of governance. Law and society studies have examined the relationship between law and social change and, more specifically, the historical evolution of welfare policies (e.g., Skocpol 1992; Sterett 1997; Fraser \& Gordon 1994; Handler \& Hasenfeld 1991; Melnick 1994; and most recently Bussiere). Further, recent studies examine the effects of enacted law on interpretations of everyday life and the identity of subjects (Bumiller 1988; Yngvesson 1993; Ewick \& Silbey 1995; Sarat 1990; Engel 1993; Munger \& Engel 1998; Engel \& Munger 1996; Roberts 1997), while others document processes of constituency building, media imaging, and administration (McCann 1994; Williams 1995; Edelman, Erlanger, \&c Lande 1993:498 n. 3). Fewer have studied how changing the identity of the subjects of law might initiate a cycle of enactment and interpretation of law (the classic exception is Gusfield 1963).

From the earliest formation of the American welfare state, the struggle for expansion of benefits provided to citizens has been accompanied by a struggle to define the concept of citizenship itself. In many respects, citizenship is the package of benefits pro- 
vided by the welfare state. Thus, those who are opposed to extending particular benefits have often attempted to describe potential beneficiaries as individuals whose behavior (or mere presence) undermines foundational community values. Thus, the struggle over benefits provided by the welfare state is often displaced to a struggle about the meaning of citizenship and about who should qualify for citizenship and the benefits that flow from citizenship. The struggle over welfare state benefits has become increasingly decentered as well, as symbolic politics reinforces a reflexive legality that leaves much practical decisionmaking about the meaning of citizenship to virtually autonomous public and private agencies only loosely coupled to the liberal legal state.

Thus, the most important issue for scholars in the law and society field who want to study poverty policy, brought to light by Gans's analysis of the stereotypes of the poor, is the connection between identity and governmentality. Welfare policy is not the product of interest group politics alone but rather emanates, as the reviewed authors agree, from something more fundamental about the way we conceive of the mutual responsibilities of our society and its citizens. Changing society's sense of responsibility for the poor will require nothing less than altering the historical stereotype so that the poor are perceived as entitled to the full benefits of citizenship. Exploring the relationship between the identity of the poor, welfare, governmentality, and citizenship through law and society research would deepen and enrich the research on the institutionalization of the identity of the poor begun by Handler and Hasenfeld, Bussiere, and Gans. This exploration would bring what scholars in the law and society field have learned about the two-way constitutive relationship between law and the practices of everyday experience to bear on the problem of enduring poverty and the possibilities for meaningful social change.

\section{References}

Anderson, Elijah (1990) Streetwise: Race, Class, and Change in an Urban Community. Chicago: Univ. of Chicago Press.

Bumiller, Kristen (1988) The Civil Rights Society: The Social Construction of Victims. Baltimore: Johns Hopkins Univ. Press.

Calavita, Kitty (1992) Inside the State: The Bracero Program, Immigration, and the I.N.S. New York: Routledge.

DiMaggio, Paul J., \& Walter W. Powell, eds. (1991) "Introduction," in Powell \& DiMaggio, eds. 1991.

Duneier, Mitchell (1992) Slim's Table: Race, Respectability, and Masculinity. Chicago: Univ. of Chicago Press.

Edin, Kathryn, \& Laura Lein (1997) Making Ends Meet: How Single Mothers Survive Welfare and Low Wage Work. New York: Russell Sage Foundation. 
Edelman, Lauren B., Howard S. Erlanger, \& John Lande (1993) "Internal Dispute Resolution: The Transformation of Civil Rights in the Workplace," 27 Law $\mathcal{E}^{\circ}$ Society Review 497-533.

Engel, David (1993) "Law in the Domains of Everyday Life: The Construction of Community and Difference," in A. Sarat \& T. R. Kearns, eds., Law in Everyday Life. Ann Arbor: Univ. of Michigan Press.

Engel, David M., \& Frank W. Munger (1996) "Rights, Remembrance, and the Reconciliation of Difference," 30 Law $\mathcal{E}^{2}$ Society Rev. 7-53.

Ewick, Patricia, \& Susan S. Silbey (1992) "Conformity, Contestation, and Resistance: An Account of Legal Consciousness," 26 New England Law Rev. 731-49.

- (1995) "Subversive Stories and Hegemonic Tales: Toward a Sociology of Narrative," 29 Law E Society Rev. 197-226.

- (1998) The Common Place of Law: Stories from Everyday Life. Chicago: Univ. of Chicago Press.

Fine, Michelle, \& Lois Weis (1998) The Unknown City: Lives of Poor and Working Class Young Adults. Boston: Beacon Press.

Finnegan, William (1998) Cold New World: Growing up in a Harder Country. New York: Random House.

Foucault, Michel (1977) Discipline and Punish: The Birth of the Prison. Ist American ed. New York: Pantheon Books.

Fraser, Nancy, \& Linda Gordon (1992) "Contract versus Charity: Why Is There No Social Citizenship in the United States," 22 Socialist Review 45-68.

- (1994) "A Genealogy of Dependency: Tracing a Keyword of the U.S. Welfare State," 19 Signs 309-36.

Gans, Herbert (1969) "Culture and Class in the Study of Poverty: An Approach to Anti-Poverty Research," in D. P. Moynihan, ed., On Understanding Poverty: Perspectives from the Social Sciences. New York: Basic Books.

Gilliom, John (1997) "Everyday Surveillance, Everyday Resistance: Computer Monitoring in the Lives of the Appalachian Poor," 16 Studies in Law, Politics, E' Society 275-97.

Greenhouse, Carol J. (1986) Praying for Justice: Faith, Order and Community in an American Town. Ithaca, NY: Cornell Univ. Press.

Gusfield, Joseph R. (1963). Symbolic Crusade: Status Politics and the American Temperance Movement. Urbana: Univ. of Illinois Press.

Handler, Joel F. (1978) Social Movements and the Legal System: A Theory of Law Reform and Social Change. New York: Academic Press.

(1996) Down from Bureaucracy: The Ambiguity of Privatization and Empowerment. Princeton, N.J.: Princeton Univ. Press.

Handler, Joel F., \& Yeheskel Hasenfeld (1991) Moral Construction of Poverty: Welfare Reform in America. Newbury Park, CA: Sage Publications.

Handler, Joel, \& Lucy White, eds. (1998) Hard Labor: Poor Women in the PostWelfare Era. New York: M. E. Sharpe.

Hunt, Alan (1994). Foucault and Law: Towards a Sociology of Law as Governance. Boulder, Co: Pluto Press.

Karst, Kenneth L. (1989) Belonging in America: Equal Citizenship and the Constitution. New Haven, CT: Yale Univ. Press.

- (1993) Law's Promise, Law's Expression: Visions of Power in the Politics of Race, Gender, and Religion. New Haven, CT: Yale Univ. Press.

Katz, Michael (1986) In the Shadow of the Poorhouse: A Social History of Welfare in America. New York: Basic Books.

Kost, Kathleen A., \& Frank W. Munger (1996) "Fooling All of the People Some of the Time: 1990's Welfare Reform and the Exploitation of American Values," 4 Virginia J. of Social Policy and the Law 3-126.

MacLeod, Jay (1987) Ain't No Makin' It: Aspirations and Attainment in a Low-Income Neighborhood. Boulder, CO: Westview Press. 
Marmor, Theodore R., Jerry L. Mashaw, \& Philip L. Harvey (1990) America's Misunderstood Welfare State: Persistent Myths, Enduring Realities. New York: Basic Books.

Matsuda, Mari J. (1997) "Were You There? Witnessing Welfare Retreat," 31 Univ. of San Francisco Law Rev. 779-88.

McCann, Michael W. (1994) Rights at Work: Pay Equity Reform and the Politics of Legal Mobilization. Chicago: Univ. of Chicago Press.

McCluskey, Martha (1996) "Economic Illusions in Social Welfare Cuts." MS. on file with the author.

Melnick, R. Shep (1994) Reading between the Lines: Interpreting Welfare Laws. Washington: Brookings Institution.

Meyer, John W., \& Brian Rowan (1991) "Institutionalized Organizations: Formal Structure as Myth and Ceremony," in Powell \& DiMaggio, eds. 1991.

Meyers, Marvin (1960) The Jacksonian Persuasion: Politics and Belief. Stanford, CA: Stanford Univ. Press.

Munger, Frank W. (1993) "Sociology of Law for a Postliberal Society," 27 Loyola Law Rev. 89-126.

- (1998) "Mapping Law and Society," in A. Sarat, eds., Crossing Boundaries: Traditions and Transformations in Law and Society Research. Evanston, IL: Northwestern Univ. Press.

Munger, Frank W., \& David M. Engel (1998) "Civil Rights and Self-Concept: Life Stories of Law, Disability and Employment," 35 Droit et Cultures 43-73.

Newman, Katherine S. (1988) Falling from Grace: The Experience of Downward Mo bility in the American Middle Class. New York: Free Press.

Newman, Katherine, \& Chauncy Lennon (1995) "The Job Ghetto," American Prospect, Summer, pp. 66-67.

Noble, Charles (1997) Welfare as We Knew It: A Political History of the American Welfare State. New York: Oxford Univ. Press.

Orloff, Ann S. (1993) The Politics of Pensions: A Comparative Analysis of Britain, Canada and the United States, 1880-1940. Madison: Univ. of Wisconsin Press.

Piven, Francis F., \& Richard Cloward (1971) Regulating the Poor: The Functions of Public Welfare. New York: Pantheon Books.

Powell, Walter W., \& Paul J. DiMaggio, eds. (1991) The New Institutionalism in Organizational Analysis. Chicago: Univ. of Chicago Press.

Quadagno, Jill S. (1994) The Color of Welfare: How Racism Undermined the War on Poverty. New York: Oxford Univ. Press.

Rainwater, Lee (1970) "Neutralizing the Poor and Disinherited: Some Psychological Aspects of Understanding the Poor," in Vernon L. Allen, ed., Psychological Factors in Poverty. Chicago: Markham Press.

Roberts, Dorothy E. (1997) "Unshackling Black Motherhood," 95 Michigan Law Rev. 938-69.

Rubin, Lillian B. (1994) Families on the Fault Line: America's Working Class Speaks about the Family, the Economy, Race, and Ethnicity. New York: Harper Collins.

Sarat, Austin (1990) “. . . The Law Is All Over," 2 Yale J. Law $\mathcal{E}$ the Humanities $343-80$.

Sarat, Austin, \& Thomas R. Kearns (1993) "Across the Great Divide," Introduction, in A. Sarat \& T. R. Kearns, eds., Law in Everyday Life. Ann Arbor: Univ. of Michigan Press.

Shamir, Ronen (1993) "Professionalism and Monopoly of Expertise: Lawyers and Administrative Law, 1933-1937," 27 Law E' Society Rev. 361-97.

Shapiro, Susan S. (1986) Wayward Capitalists: Target of the Securities and Exchange Commission. New Haven, CT: Yale Univ. Press.

Shklar, Judith N. (1991) American Citizenship: The Quest for Inclusion. Cambridge: Harvard Univ. Press.

Simon, Jonathan (1992) "The Long Walk Home' to Politics," 26 Law Ev Society Review 923-41.

_ (1997) "Governing through Crime." MS. on file with the author. 
Skocpol, Theda (1992) Protecting Soldiers and Mothers: The Political Origins of Social Policy in the U.S. Cambridge: Harvard Univ. Press, Belknap Press.

Smith, Rogers M. (1988) "Constitutional Interpretation and Political Theory: American Legal Realism's Continuing Search for Standards," Polity 15 (Summer 1983): 492-514.

Sterett, Susan (1997) "Serving the States: Constitutionalism and Social Spending, 1860s-1920s," 22 Law E゚ Social Inquiry 311-56.

Suchman, Mark, \& Lauren Edelman (1996) "Legal Rational Myths: The New Institutionalism and the Law and Society Tradition," 21 Law E Social Inquiry 903-41.

Teubner, Gunther (1983) "Substantive and Reflexive Elements in Modern Law," 17 Law E' Society Rev. 237-85.

Weir, Margaret (1992) "Ideas and the Politics of Bounded Innovation," in S. Steinmo, K. Thalen, \& F. Longstreth, eds., Structuring Politics. New York: Cambridge Univ. Press.

White, Lucie (1993) "No Exit: Rethinking Welfare Dependency: From a Different Ground," 81 Georgetown Law J. 1961-2002.

Williams, Lucy A. (1995) "Race, Rat Bites and Unfit Mothers: How Media Discourse Informs Welfare Legislation Debate," 22 Fordham Urban Law J. 1159-96.

Wilson, William Julius (1996) When Work Disappears: The World of the New Urban Poor. New York: Alfred A. Knopf.

Yngvesson, Barbara (1993) Virtuous Citizens, Disruptive Subjects: Order and Complaint in a New England Court. New York: Routledge.

Zucchino, David (1997) Myth of the Welfare Queen: A Pulitzer Prize-Winning Journalist's Portrait of Women on the Line. New York: Scribner.

Zucker, Lynne G. (1991) "The Role of Institutionalization in Cultural Persistence," in Powell \& DiMaggio, eds 1991.

\section{Cases Cited}

Dandridge v. Williams, 397 U.D. 471 (1970).

Shapiro v. Thompson, 394 U.S. 618 (1969). 
